4. Загальне цивільне уложення Австрійського імперії 1811 року // Кодифікація цивільного законодавства на українських землях: Т.1 / Уклад.: Ю. В. Білоусов, І. А. Калаур, С. Д. Гринько та ін. / За ред. Р. О. Стефанчука та М. О. Стефанчука. К.: Правова єдність, 2009. С. 1025-1149.

5. Безклубий I., Кочкодан I. Зобов’язання, що не мають ознак правової відповідальності // Відповідальність у приватному праві: монографія / заг. ред. І. Безклубого. К.: Грамота, 2014. С.154-258.

6. Цивільне право України. Особлива частина: підручник / за ред. О. В. Дзери, Н. С. Кузнєцової, Р. А. Майданика. 3 вид., перероб. і допов. К.: Юрінком Інтер, 2010. 1176 с.

7. Зубар В. М. Зобов'язання, що виникають з ведення чужих справ без доручення: автореф. дис. ... канд. юрид. наук. К., 2001. 18 с.

8. Новицкий И. Б. /Деятельность в интересе второго лица без поручения // Отдельные виды обязательств / Под ред. К. А. Граве и И. Б. Новицкого. М.: Госиздат юрид. лит., 1954. С. 335- 351.

9. Венедіктова I. В. Методологічні засади охоронюваних законом інтересів у приватному праві: монографія. Х.: Нове Слово, 2011. 260 с.

10. Науково-практичний коментар Цивільного кодексу України: у 2-х т. 5-те вид., перероб. і допов. / за відповід. ред. О. В. Дзери (кер. авт. кол), Н. С. Кузнєцової, В. В. Луця. К., 2013. Т. 2. С. 890.

11. Рішення Святошинського суду м. Києва від 5 листопада 2014 р. по справі № 2/759/2992/14. URL: reyestr.court.gov.ua/Review/41482855 (дата звернення: 04.01.3019 p.).

12. Рішення Печерського суду м. Києва від 13 червня 2016 р. по справі № 757/17501/15-ц. URL: http://reyestr.court.gov.ua/Review/58594548 (дата звернення: 04.01.3019р.).

13. Харитонов Е. О. Обязательства, возникающие из ведения дел без поручения в советском гражданском праве: автореф. дис. ... канд. юрид. наук. Х., 1980. 26 с.

14. Пленюк М. Д. Підстави виникнення зобов'язальних правовідносин в механізмі правового регулювання: монографія. К.: НДІ приватного права і підприємництва імені академіка Ф. Г. Бурчака НАПРН України, 2016. $356 \mathrm{c.}$

15. Харитонов Є. О. Цивільні правовідносини: навч. посіб. / Є. О.Харитонов, О. І. Харитонова. К.: Істина, 2008. 304 с.

16. Гражданское уложение Германии. Пер. с нем.; науч. ред. А. Л. Маковский и др. М.: Волтерс Клувер, 2004. 816 с.

17. Кузнєцова Н. С. Вибрані праці. К.: ПрАТ «Юридична практика», 2014. 544 с.

\title{
Zaika Y. Actions in another's interests as ground for obligation
}

The article considers the issues of protection of property rights of third parties without comission. Author analyzes the conditions of occurence of obligations of compensation damages to persons acting in someone else's interest. It is proposed to consider actions in the interest of other people as a quasi-contract in the section of contract law.

Keywords: obligations, grounds for obligations, actions in another's interest, compensation of expenses.

\section{СТАНОВЛЕННЯ ТА РОЗВИТОК ІНСТИТУТУ ПРИЙОМНОЇ СІМ'̈̈ У ВІТЧИЗНЯНОМУ ЗАКОНОДАВСТВІ}

\author{
https://doi.org/10.32849/2409-9201.2019.19.17
}

\section{Козак О. М.,}

аспірантка відділу проблем приватного права НДІ приватного права і підприємництва імені академіка Ф. Г. Бурчака НАПрН Украӥни

Увагу зосереджено на аналізі етапів еволючійного розвитку інституту прийомної сім'ї у вітчизняному законодавстві. Констатовано зародження правових форм влаштування дітей-сиріт та дітей, позбавлених батьківського піклування, вже у княжу добу, оскільки вже в ті часи допомогу щодо опіки над сиротами надавали не лише монастирі, а й приватні особи. Встановлено перші спроби виокремлення на законодавчому рівні з-поміж інших форм влаштування дітей-сиріт та дітей, позбавлених батьківського піклування, такої форми, як прийомна сім'я із середини XVIII ст. Акцентується увага на спробі розробників Цивільного кодексу Східної Галичини 1797 р. розмежувати такі правові форми влаштування дітей-сиріт та дітей, позбавлених батьківського піклування, як опіка та піклування, патронат, прийомна сім'я. Встановлено непоширеність сімейних форм виховання дитини в радянську добу. 3 середини 90-х років констатовано виокремлення на законодавчому рівні нової правової форми влаштування дітей-сиріт та дітей, позбавлених батьківського піклування, у прийомну сім'ю. 
Ключові слова: інститут прийомної сім’ї, діти-сироти, діти, позбавлені батьківського піклування, прийомні батьки, правова форма влаштування дітей, договір.

Аналіз етапів еволюційного розвитку інституту прийомної сім’ї у вітчизняному законодавстві доцільно розпочати із констатації факту, що на відміну від таких форм влаштування дітей-сиріт та дітей, позбавлених батьківського піклування, як усиновлення, опіка і піклування, інститут прийомної сім'ї є порівняно молодим правовим інститутом, розквіт якого припадає на XIX ст. Водночас говорити, що ментально цей інститут є чужорідним для вітчизняної правової системи, було б неправильно, зважаючи, що ще за період княжої доби турбота про дітей-сиріт була пріоритетом впливових приватних осіб (переважно князів та духівництва). Наприклад, одним з перших князь Ярослав Мудрий започаткував створення сирітських шкіл. У той час поступово розвивалися різні форми влаштування дітей-сиріт та дітей, позбавлених батьківського піклування, що взаємно доповнювалися та базувалися на особистому благодіянні князів та благодійницькій діяльності церкви [1, с. 32]. Так, «Уставом Святого князя Володимира, крестившаго Руськую землю, о церковных судех» виділялися основні категорії тих, про кого мали піклуватися, було визначено мету піклування, а також вирішувалося найважливіше питання фінансування закладів для піклування про незаможних, що діяли при церквах.

Найпершими письмовими джерелами, що містили норми сімейного права, можна вважати договори князів Олега й Ігоря 3 греками 907, 911 і 945 рр. Разом 3 тим окремих правових форм влаштування дітей-сиріт та дітей, позбавлених батьківського піклування, у найвідомішій і одній 3 найдавніших правових пам'яток Київської Русі - Руській Правді - не містилось, хоча правові норми, що регулювали відносини подружжя з приводу належного їм майна, там були передбачені.

На зазначеному етапі зародження правових форм влаштування дітей-сиріт та дітей, позбавлених батьківського піклування, прийомна сім'я не виокремлюється як явище, віддільне від опіки, піклування та усиновлення. Водночас вже в княжу добу після міжусобних війн, татаро-монгольських набігів тощо осиротілих дітей княжої раті приймали в свої сім’ї їх родичі або й чужі люди, особливо у випадку, коли осиротілим дітям могло належати хоч якесь майно. Інші ж позбавлені батьківського піклування діти жили за рахунок подаяння «мирської милостині».

Із занепадом Київської Русі у зв'язку із постійними міжусобними війнами частина українських земель у першій половині XIV ст. опинилася під владою Великого князівства Литовського, а частина Королівства Польського. У той період влаштування дітей-сиріт та дітей, позбавлених батьківського піклування, на територіях, що входили до складу цих держав, поступово урегульовується на законодавчому рівні. Так, вже перша редакція Статуту Великого князівства Литовського 1529 р. містила розділ 5 «Про опікунів», положення якого стосувалися виключно опіки над майном дітей. Зі змісту п. 1 розділу 5 Литовських статутів 1529 р. можемо виявити, що опікуном в той час могла бути особа, призначена як з числа родичів, так і зі сторонніх осіб [2, с. 27]. В другій («Волинській») редакції Статуту Великого князівства Литовського 1566 р., як і в третій редакції («Післялюблінській») 1588 р., присвячені опіці положення викладені ширше, однак про інші правові форми влаштування дітейсиріт та дітей, позбавлених батьківського піклування, будь-які згадки відсутні.

Вивчаючи такі історичні джерела, можемо стверджувати, що зародження правових форм влаштування дітей-сиріт та дітей, позбавлених батьківського піклування, відбувалось вже у княжу добу, оскільки вже в ті часи допомогу щодо опіки над сиротами надавали не лише монастирі, а й приватні особи. Так, осиротілих дітей брали і приватні особи, які виховували і навчали таких сиріт, а після досягнення певного віку відпускали в світ без права на спадкування майна таких «благородних батьків». Хоча сучасного розуміння цей договірний інститут як належно оформлений документ, що підтверджує права й обов'язки прийомних батьків, органів влади та дітей, в той час ще не набув.

У період козацької доби та Гетьманщини набули значного розвитку братства, при яких обов'язково влаштовувалися школи, богодільні і будинки для прочан. Церква та братства були не лише основним джерелом самої ідеї громадського піклування, а й інститутом іiї реалізації. Зокрема, їх значення виходило далеко за рамки звичайної філантропічної діяльності. Вони були втіленням гуманістичних ідей на старість, немічність, убозтво, сирітство. Ці явища суспільного життя народ вважав лихом, а не приниженням [3, с. 34]. Випускники таких закладів виходили підготовленими до подальшого життя, мали не лише сільськогосподарські навички, а й володіли ремеслами. Головним принципом організації подібних закладів було самозабезпечення. Однак в юридичній літературі зазначається, що у виховних будинках того часу смертність сягала 75\%, тому з 1811 р. сиріт частіше передавали у родини [4].

Більшого поширення після національно-визвольної війни 1648-1657 рр. набули доброчинномеценатські справи гетьманів, козацької старшини та заможних козаків. Щоправда, таку діяльність можна охарактеризувати як приватну доброчинність, натомість загальнодержавного чи хоча б місцевого громадського характеру вона ще не набула. Тобто у сфері сімейно-правових відносин провідну роль у часи Гетьманщини відіграють різноманітні особисті вольності. Як зазначається 3 
цього приводу в юридичній літературі, тільки із посиленням державницьких позицій починаються перші усвідомлені кроки державної влади у боротьбі з жебрацтвом, оскільки безконтрольне роздавання милостині призвело до розквіту і поширення такого соціального феномена, як професійне жебрацтво $[5$, c. 51].

Значення будь-яких інших правових форм влаштування дітей-сиріт, крім встановлення опіки над ними, не змінилися і впродовж XVI - XVIII ст. Наприклад, у збірнику «Прав, за якими судиться Малоросійський народ» (артикул 4 гл. 11) 1793 р. чітко окреслено перелік осіб, які повинні бути опікунами дітей-сиріт. Крім того, на опікуна перед вступом у такі правовідносини покладався обов' язок у присутності двох поважних осіб з органів влади здійснити опис всього належного осиротілій дитині рухомого та нерухомого майна, а також присягнути «стараться о добром и честном тех же сирот, как бы своих собственных детей, воспитании, дабы праздно, и всуе лет своих не теряя, обучаемы были в книжном чтении, в потребных науках, и в других политических обхождениях, или смотря по породе их в художних каких мастерствах, и не претерпевали б в корме и одеянии нужды, но надлежащее в том бы по пропорции имения их имели довольство» (артикул 7 гл. 11) [2, с. 524-525]. І3 такого (залучення двох представників органів влади) можемо дійти висновку про фактичне зародження інституту прийомної сім'ї, де гарантом належного виконання обов'язків прийомних батьків виступає держава в особі своїх органів. Окремо в зазначеному нормативно-правовому акті врегульовувались питання заміни опікуна, обов'язку останнього представляти права та інтереси сироти в різних органах, збереження майна сироти, відповідальності опікуна за неналежне виконання покладених обов'язків тощо.

Особливістю того часу було те, що домовленість про передання дитини-сироти під опіку досягалась в усній формі і фактично до кінця XVII ст. зазначені підходи не змінювались. Однак уже починаючи 3 XVIII ст., поступово розпочинається процес оформлення таких домовленостей у письмовій формі, особливо якщо сирота володів земельною ділянкою чи іншим нерухомим майном. До того ж, чим більше загострювалася земельна проблема, тим частіше українці надавали перевагу письмовій формі, яка, таким чином, ставала обов'язковою [6, с. 13].

У той час на рівні царських указів встановлювалася нова система адміністративно-територіального устрою, в межах якої створювалися спеціальні місцеві піклувальні органи у вигляді Приказів громадського піклування. Так, царським Указом «Установи для управління губерній Всеросійської імперії» 1775 р. закріплювалось цікаве для нашого дослідження положення, за яким у разі недоцільності створення сирітського будинку з фінансових міркувань, Приказ громадського піклування вправі віддати сиріт на утримання та виховання за окрему плату на виховання приватним особам [7, с. 16-17]. Наприклад, в ті часи опікун малолітньої дитини отримував 3 доходів малолітньої дитини 5\% щорічно, а в Чернігівській та Полтавській губерніях - 10\% чистих доходів щорічно [8, с. 438]. Тобто, можемо констатувати перші спроби виокремлення на законодавчому рівні 3-поміж інших форм влаштування дітей-сиріт та дітей, позбавлених батьківського піклування, такої форми, як прийомна сім’я.

Прикладом вищенаведеного можуть бути положення глави 5 частини 1 Цивільного кодексу Східної Галичини 1797 р., що діяв на території Східної Галичини та Буковини, які перебували під гнітом Австро-Угорської імперії. Так, зазначена глава розпочинається із закріпленого законодавчо обов'язку держави забезпечити наявність опікуна над сиротою чи дитиною, позбавленою батьківського піклування, та піклувальника над їх майном (§ 164-165). Крім того, тогочасний законодавець АвстроУгорської імперії, у складі якої знаходились Східна Галичина та Буковина, закріпив чіткий перелік осіб, які не можуть бути опікунами, до яких відніс: жінок, священиків, іноземців, іновірців, військових, осіб, яких батько відсторонив від опіки, заявивши про це, а також осіб, що недружньо налаштовані проти дитини чи мають вже під опікою трьох і більше дітей чи більше п’яти власних дітей або внуків.

Цікавим та таким, що свідчить про договірну природу правових форм влаштування дітей-сиріт та дітей, позбавлених батьківського піклування, є положення $§ 181$ Цивільного кодексу Східної Галичини 1797 р., де закріплювалась цивільно-правова відповідальність опікуна, який приховав свою неспроможність до здійснення опіки, або ж судді, що свідомого призначив опікуном таку особу, у формі відшкодування, завданих дитині реальних збитків, а також упущеної вигоди. Більше того, як було передбачено § 247, «навіть члени суду щодо опіки, які недбало виконували свої функції на шкоду неповнолітньому, відповідальні за невиконання своїх обов'язків, і якщо немає жодних інших способів компенсації, то вони зобов' язані компенсувати доведені збитки» [9, с. 67].

Підсумовуючи зазначений період, доцільно підкреслити, що розробники Цивільного кодексу Східної Галичини 1797 р. в той час ще не намагались розмежувати такі правові форми влаштування дітей-сиріт та дітей, позбавлених батьківського піклування, як опіка та піклування, патронат, прийомна сім'я, водночас уже закріплювали їх відмінні ознаки в інституті опіки та піклування. Прикладом зазначеного є положення § 183, де передбачено обов'язкову участь органу державної влади (суду) в отриманні права стати опікуном, обов’язкову перевірку таких осіб, наявність у останніх можливості навчати особу, якою він опікується, порядності, побожності та доброчесності, намагання виховати дитину гідним громадянином, репрезентувати іiі в суді та поза ним, надійно та старанно управляти іiі 
майном і у всьому поводитися відповідно до приписів закону. Тобто вже в той час виокремлюються спільні для всіх форм влаштування дітей-сиріт та дітей, позбавлених батьківського піклування, ознаки: забезпечення нормального розвитку, виховання, спілкування таких осіб, підтримки на належному рівні особистісних зв'язків із суспільством, у тому числі і шляхом надання допомоги у здійсненні майнових прав. Позитивним $є$ те, що зазначені обов'язки знайшли своє відображення (хоча й в дещо трансформованому вигляді) й в сучасних законодавчих актах України.

Аналізуючи Загальне цивільне уложення Австрійської імперії 1811 р., слід одразу ж зазначити, що в цьому кодифікованому акті, на відміну від Цивільного кодексу Східної Галичини, законодавчо виокремлено, разом із інститутом опіки та піклування, такі правові форми влаштування дітей-сиріт та дітей, позбавлених батьківського піклування, як усиновлення та прийняття дитини на виховання. Так, $\S 186$ Загального Цивільного уложення Австрійської імперії 1811 р. передбачалось, що права i обов'язки усиновителів і усиновлених не можуть застосовуватись до дітей, що приймаються тільки на виховання. Приймати в сім'ю на виховання дозволялося кожному. Якщо ж сторони побажають укласти договір про прийняття на виховання, то останній мав бути затверджений судом. Приймаючі на виховання особи не мають права вимагати відшкодування витрат на виховання [2, с. 1025], однак суд міг призначити старанним опікунам з чистого доходу щорічну винагороду в розмірі не більше $5 \%$ чистого доходу або чотирьох тисяч гульденів [8, с. 437]. Тенденція щодо передання дітей на виховання у прийомні сім’ї пояснювалась значним ростом кількості безпритульних дітей та погіршенням умов їх життя, що відбилося у зростанні показників смертності. Саме ця обставина, на думку окремих дослідників, стала причиною заборони відкриття нових виховних будинків [10, с. 2$].$

Наступний період розвитку інституту прийомної сім’ї у вітчизняному законодавстві пов’язаний 3 буремними подіями революції 1905-1907 pp., Першою світовою війною, революцією 1917 р., що призвели до різкого збільшення чисельності дітей-сиріт, бездоглядних та безпритульних дітей [11, с. 112]. Саме в цей період зростання чисельності дітей-сиріт та дітей, позбавлених батьківського піклування, спостерігається посилення ролі держави у створенні умов для їх повноцінного фізичного, інтелектуального, духовного, морального і соціального розвитку. I, дійсно, доводиться спостерігати пожвавлення активних дій у питаннях влаштування соціально незахищених верств населення (особливо дітей, батьки яких віддали своє життя на полях битви за українську державність) з боку Української народної республіки, Західно-Української народної республіки, Гетьманату Скоропадського та Української держави.

Більш серйозні зміни у питанні влаштування дітей-сиріт та дітей, позбавлених батьківського піклування, відбулися після силового захоплення влади в Україні більшовиками і примусовим входженням України до складу Радянського Союзу. В цей час сімейні форми влаштування дітей не отримали державної підтримки. Натомість перевага надавалась створенню дитячих приймально-розподільчих пунктів, дитячих будинків різного типу, дитячих містечок, колоній-комун, в яких діти отримували виховання, освіту тощо. Загалом створювана в той час система соціального забезпечення дітей-сиріт охоплювала дитячі будинки різних категорій (дошкільні, шкільні, 3 професійним навчанням, лікувальні, для інвалідів тощо), а також трудові колонії і трудові комуни для важковиховуваних дітей.

3 цього приводу доцільно нагадати, що саме сімейні форми виховання дитини в радянський період були менш поширеними, проте вперше радянський уряд був змушений вдатися до політики піклування про дітей-сиріт саме через інститут прийомної сім’ї вже на початку 20-х років XX ст., коли було встановлено незадовільний рівень їх утримання у таких дитячих будинках (бруд, голод, напівзруйновані приміщення). У 1925 р. Народний комісаріат з охорони здоров'я видав інструкцію «Об отдаче покинутых детей на воспитание из учреждений Охраны материнства и младенчества», в якому наголошувалося на необхідності передання дітей в сім’ї, де є члени комуністичних організацій. На виховання у прийомні сім’ї передавалися здорові діти віком від 3-х місяців та старші. Перевага надавалась сім'ям бездітним або небагатодітним родинам [12, с. 13].

Цікавим стосовно нашого дослідження є документ 1928 р. «Про порядок і умови передачі вихованців дитячих будинків та інших неповнолітніх трудящим в містах і робочим в селах». Зазначений нормативно-правовий акт передбачав можливість передання дітей на виховання громадянам на основі укладеного у письмовій формі договору. Істотними умовами такого договору про передання вихованця дитячого будинку чи іншої неповнолітньої особи належали: обов'язок утримувати дитину нарівні з іншими членами сім’ і; тривалість договірних відносин із зазначенням певного строку, але не менше трьох місяців; форма і розмір допомоги вихованцю після припинення договору; порядок дострокового розірвання договору тощо. Особа, що погоджувалась прийняти таку дитину у свою сім'ю на таких договірних засадах, отримувала серйозну державну підтримку за рахунок місцевих коштів шляхом одноразової виплати для потреб сім’ї. Тобто тогочасний договір про влаштування дітей-сиріт та дітей, позбавлених батьківського піклування, на виховання у прийомну сім'ю характеризувався як двосторонній, оплатний, консенсуальний і, що найбільш нехарактерно для того часу, добровільний договір, а наявність різного роду гарантованих державою пільг сприяло широкому його розвиткові на практиці, коли найближчі родичі приймали у прийомну сім’ю таких дітей, у тому числі й у зв’язку із перспективою отримання певних різного роду пільг та матеріальної допомоги. 
Наступною важкою віхою нашої історії стало масове знищення соціально активного населення України, що пов'язано з голодомором 1932- 1933 рр., хвилею сталінських репресій, а також Другою світовою війною. Дітей, що примусово позбавлялись батьківської опіки, розміщували в сумнозвісні «приймачі-розподільники», а звідти відправляли до дитячих будинків і ясел Наркомату охорони здоров’я. Безпрецедентним за своєю жорстокістю був Оперативний наказ № 00486 народного комісара внутрішніх справ СРСР Миколи Сжова від 15 серпня 1937 р. Відповідно до нього каральна система не жаліла ні дітей, ні дружин ворогів Радянського Союзу. Політичних сиріт примусово засилали до інтернатів системи Наркомату освіти, охорони здоров'я і спеціальних закладів, створених органами НКВС [13]. Як вбачається зі змісту цього нелюдського наказу, основна біда цих дітей полягала навіть не в тому, що вони ставали сиротами при живих батьках, а в тому, що їх заборонялось приймати сім'ям їх родичів. Відповідно, держава імперативно визначала єдиний шлях такій дитині - дитячий будинок-інтернат з усіма можливими наслідками (втрата права на сім'ю, щасливе дитинство, виховання в сім'ї тощо). У свідоцтві про народження такої дитини в графах «відомості про батьків» було пусте місце, а самих дітей (особливо молодшого віку) таким чином примушували забути або (щодо старших) відмовитися від засуджених батьків.

У цей час дедалі більше акценти зміщуються у бік доцільності створення спеціальних диференційованих шкіл і дитячих будинків [14, с. 37], що свідчить на користь висновку про подальше превалювання в системі соціального захисту дітей-сиріт їх влаштування в дитячі заклади інтернатного типу. Так, протягом фактично п'яти років усі дитячі будинки були реформовані на школи-інтернати [15, c. 91].

Разом із тим час підтвердив неможливість заміни сімейного виховання вихованням у будинкахінтернатах, які продемонстрували обмежений порівняно 3 індивідуальним вихованням спектр можливостей для подальшої соціальної адаптації дітей-сиріт. Помилковість підходу щодо відмови від можливостей виховання дітей-сиріт та дітей, позбавлених батьківського піклування, в сім'ї було прямо підтверджено політикою СССР 80 -х років XX ст., коли пріоритетне місце в цьому процесі знову повертається насамперед до сімейних форм влаштування таких дітей.

Саме тому із здобуттям незалежності України та ратифікацією незалежною Україною Конвенції ООН про права дитини у 1991 р. було закріплено пріоритет виховання дітей саме у сім’ї, адже лише тоді дитина може бути повністю підготовлена до самостійного життя у суспільстві. 3 цією метою наприкінці 90-х років XX ст. було прийнято рішення «реорганізувати» такі будинки-інтернати в прийомні сім’ї шляхом прийняття на рівні Кабінету Міністрів України Постанови «Про проведення експерименту щодо створення прийомних сімей в окремих регіонах України». Як видається, саме 3 цього моменту можна стверджувати про виокремлення на законодавчому рівні нової правової форми влаштування дітей-сиріт та дітей, позбавлених батьківського піклування, у прийомну сім'ю.

Результатом такого експерименту з утворення прийомних сімей в окремих областях України стало прийняття у квітні 2002 р. єдиного «Положення про прийомну сім’ю», у п. 2 якого передбачено уже зовсім інше бачення поняття прийомної сім'ї, ніж у вищенаведених «експериментальних положеннях». Більше того, зазначені новели Постанови Кабінету Міністрів України від 26 квітня 2002 р. № 565 знайшли своє відображення в законах України «Про забезпечення організаційно-правових умов соціального захисту дітей-сиріт та дітей, позбавлених батьківського піклування» та «Про основи соціального захисту бездомних громадян і безпритульних дітей».

Тобто наведені факти свідчать про намагання держави насамперед відійти від усталених минулих підходів до вирішення проблем влаштування дітей-сиріт та дітей, позбавлених батьківського піклування, шляхом удосконалення механізму врегулювання цих відносин на договірному (індивідуальному) рівні через створення сприятливих умов для розвитку інституту прийомного виховання та його форм прийомної сім'ї, дитячого будинку сімейного типу, патронату як на рівні закону, так і на рівні його практичної реалізації. Водночас сьогодні доводиться констатувати й той факт, що всупереч стрімкому розвитку сімейних форм виховання, інтернатні заклади й далі продовжують поповнюватися дітьми. Як видається, це є наслідком недостатнього розроблення механізму отримання відповідного статусу прийомними батьками та прийомними дітьми, адже отримання цього статусу є справою непростою та тривалою в часі, оскільки потребує збору документів, пошуку потенційних прийомних батьків, їх перевірку, проходження курсу підготовки і рекомендації відповідного центру соціальних служб для сім'ї, дітей та молоді, розгляду та прийняття рішення про утворення прийомної сім'ї відповідним органом місцевого самоврядування, розробки та укладання договору про влаштування дітей до прийомної сім'ї на виховання та спільне проживання тощо.

\section{СПИСОК ВИКОРИСТАНОЇ ЛІТЕРАТУРИ:}

1. Падун Є. В. Інститут прийомного виховання у сімейному праві України: дис. ... канд. юрид. наук: 12.00.03. Київ: Національна академія внутрішніх справ, 2017. С. 32.

2. Кодифікація цивільного законодавства на українських землях. Т. 1 / уклад.: Ю. В. Білоусов, I. Р. Калаур, С. Д. Гринько та ін. / За ред. Р. О. Стефанчука та М. О. Стефанчука. Київ: Правова єдність, 2009. С. 27, 524-525, 1025. 
3. Особенности развития личности ребенка, лишенного родительського попечительства. Дети с отклоняюшимся поведением / под ред. В. С. Мухиной. Москва, 1989. С. 34.

4. Лукашенкин А. Ведомственные учреждения Императрицы Марии: губернское попечительство детских приютов. Доклад на региональной конференции по теории и практике благотворительной деятельности. URL: hptt://ngo.pskov.ru /hgo2002/topic/doklad (дата звернення: 12.09.2018).

5. Романюк У. В. Патронат як форма влаштування дітей-сиріт і дітей, позбавлених батьківського піклування : дис. ... канд. юрид. наук: 12.00.03. Хмельницький: Хмельницький університет управління та права, 2018. С. 51.

6. Хобор Р. Б. Шлюбний договір як регулятор майнових відносин подружжя: монографія. Тернопіль: Підручники і посібники, 2017. С. 13.

7. Фетисова О. В. Приемная семья как способ семейного воспитания детей-сирот и детей, оставшихся без попечения родителей, по законодательству Российской Федерации: дис. ...канд. юрид. наук: 12.00.03. Москва: Российский государственный социальный университет, 2005 С. 16-17.

8. Загоровский А. И. Курс семейного права / под ред. и с предисл. В. А. Томсинова. Москва: Издательство «Зерцало», 2003. С. 438, 437.

9. Цивільний кодекс Галичини: пер. $з$ нім. Мар'яна Мартинюка, Олени Павлишинець. ІваноФранківськ: Вавилонська бібліотека, 2017. С. 67.

10. Шукуров Р. А. Приемная семья по семейному праву Российской Федерации: автореф. дисс. ... канд. юрид. наук: 12.00.03. Москва. 2004. С. 2.

11. Артюшкіна Л. М., Поляничко А. О. Сирітство в Україні як соціально-педагогічна проблема (соціально-правовий аспект). Монографія. Суми, 2002. С. 112.

12. Шевченко Я. Н. Основы семейного законодательства. Київ: Вища школа. 1982. С. 13.

13. Гуцула В. Доля дітей «ворогів народу» в СРСР // Збруч. 21.05.2015. URL : http://zbruc.eu/node/ 44121 (дата звернення: 29.09.2018).

14. Гончаренко В. Д., Рогожин А. Й., Святоцький О. Д. Хрестоматія з історії держави та права України. Т.1: 3 найдавніших часів до початку XX ст.: навч. посіб для юрид. вищих навч. закладів і фак. У 2-х т. / за ред. члена-кореспондента АПН України В. Д. Гончаренка. Київ, 1997. С. 37.

15. Положение детей в СССР. 1990 год. Состояние. Проблемы. Перспектива. Москва, 1990. С. 91.

Kozak O. Of the institute of the accepted family in domestic legislation

The article focuses on the analysis of the analysis of the stages of evolutionary development of the foster family institution in the domestic legislation. The emergence of legal forms of placement of orphans and children deprived of parental care is already at the princely age, since at that time assistance for the care of orphans was provided not only by monasteries but also by private individuals. The first attempts at legislative separation among other forms of placement of orphans and children deprived of parental care in the form of a foster family from the middle of the XVIII century were established. the focus is on the attempt by developers of the Civil Code of Eastern Galicia in 1797 to distinguish between such legal forms of placement of orphans and children deprived of parental care as guardianship and guardianship, patronage, foster family. The prevalence of family forms of child upbringing in the Soviet era was established. Since the mid-1990s, the new legal form of placement of orphans and children deprived of parental care in the foster family has been identified at the legislative level.

Keywords: institute of adoptive family, orphans, children deprived of parental care, foster parents, legal form of child placement, contract.

\title{
СТРОКИ (ТЕРМІНИ) У МЕХАНІЗМІ ПРАВОВОГО РЕГУЛЮВАННЯ ЦИВІЛЬНИХ ВІДНОСИН
}

\author{
https://doi.org/10.32849/2409-9201.2019.19.18
}

\section{Луць В. В.,}

доктор юридичних наук, професор, академік НАПрН України, провідний науковий співробітник НДІ приватного права і підприємниџтва імені академіка Ф. Г. Бурчака НАПрН Украӥни

У статті досліджується роль строків і термінів як часових категорій на різних стадіях механізму правового регулювання майнових та особистих немайнових (цивільних) відносин; обтрунтовується авторська позиція про те, щьо будучи часовою формою розвитку цивільних правовідносин, формою існування та здійснення (виконання) суб'єктивних прав та обов'язків цивільно-правові строки не посідають самостійного місия в загальній системі юридичних фактів і породжують юридичні наслідки лише у зв 'язку з діями та подіями. 